\title{
Analysis of Super Duplex Stainless Steel Properties as an Austenite-Ferrite Composite
}

\author{
Fady M. Elsabbagh, Ahmed El-Sabbagh, Rawia M. Hamouda, Mohamed A. Taha* \\ Faculty of Engineering, Ain-Shams University, Cairo, Egypt \\ Email: *m_ataha@yahoo.com
}

Received 22 October 2015; accepted 18 December 2015; published 21 December 2015

Copyright ( 2015 by authors and Scientific Research Publishing Inc.

This work is licensed under the Creative Commons Attribution International License (CC BY). http://creativecommons.org/licenses/by/4.0/

(c) $\underset{\mathrm{EY}}{\mathrm{E}}$ Open Access

\section{Abstract}

Super duplex stainless steel (SDSS) is considered as a composite formed from a microstructure of an approximately equal mixture of two primary constituents $(\gamma$-austenite and $\alpha$-ferrite phases) and the secondary precipitates (sigma, chi, alpha-prime, etc.). While the formation of these phases affects the properties of SDSS, however there are no rules that govern the relationship. In this work, the relationship between toughness as well as corrosion behavior of SDSS (UNS 32760) and the microstructure constituents has been experimentally investigated, and analyzed in view of the composite principles. Another two stainless steels namely; fully austenitic SASS (UNS N08367) and fully ferritic FSS (UNS S42900) are considered to simulate the constituent's primary components in the composite which are austenite $\gamma$ and ferrite $\alpha$ phases respectively. Samples of the composite and constituent's steels are first subjected to solution annealing, where the composite steel has a microstructure of $\gamma$ austenite and $\alpha$ ferrite grains. They were then subjected to similar different isothermal heat treatment cycles, for the formation of secondary phase precipitations within the transformation temperature ranges of each of $\gamma$ and $\alpha$ primary grains. Impact toughness and corrosion (specific weight loss) tests were conducted on the annealed and isothermally treated samples. The composite rule of the mixtures (ROM) is used to analyze the relationship between the toughness and corrosion properties in the composite SDSS and the SASS and FSS constituent's steels. The analysis indicates that in case of toughness, ROM applies well on the composite and constituents' steels in the solution annealed and in isothermal treatment conditions, where better matching between experimental and calculated results is observed. When applying ROM for corrosion weight loss, a great difference is found between the experimental and calculated results, which is much reduced for solution treated samples ferritic and austenitic temperature ranges of $480^{\circ} \mathrm{C}-500^{\circ} \mathrm{C}$ and $700^{\circ} \mathrm{C}-750^{\circ} \mathrm{C}$ as for ferrite and austenite respectively.

\footnotetext{
"Corresponding author.
} 
Keywords

Duplex Stainless Steel, Impact Toughness, Corrosion Resistance, Modelling

\section{Introduction}

Duplex stainless steels are formed from a microstructure of an approximately equal mixture of two prime phases, which are $\gamma$-austenite and $\alpha$-ferrite phases, thus they are named austenitic-ferritic stainless steels. The merits of the two phases are granted, which are the high corrosion resistance and ductility of the austenitic phase, plus the high mechanical strength of the ferritic phase [1]-[7]. Their higher strength and corrosion resistance make them suitable for very demanding applications with very aggressive environments, such as oil and gas, seawater and marine engineering, chemical and food industries.

However, the disadvantage of austenite-ferrite mixture is the susceptibility to precipitation of secondary intermetallic phases when exposed to temperatures ranging from $350^{\circ} \mathrm{C}$ to $900^{\circ} \mathrm{C}$ [1] [2] [8]-[15]. These precipitates are dangerous intermetallic phases resulting in detrimental effects on impact toughness and corrosion resistance [1] [2] [9] [10]-[15].

Various intermetallic phases ( $\sigma$-phase, $\chi$-phase, carbides and nitrides) have been found to occur at the $\alpha / \gamma$ interface [1] [2] [9]-[15]. Other authors [16] [17] suggest that the precipitation of $\sigma$-phase is associated with the precipitation of $\chi$-phase. If the alloy with 15 to $75 \mathrm{Cr} \%$ is heat treated or used in the temperature range $350^{\circ} \mathrm{C}$ $550^{\circ} \mathrm{C}$, spinodal decomposition occurs within $\alpha$ matrix as a decomposition into $\alpha$ and $\alpha$ [15]. Due to the embrittling effect of $\dot{\alpha}$, a serious decrease in toughness occurs, which is known as $475^{\circ} \mathrm{C}$ embrittlement [15]. Carbide and nitride precipitation in the ferrite-austenitic steels occur in the temperature range $550^{\circ} \mathrm{C}-800^{\circ} \mathrm{C}$. Chromiumrich precipitates, which are formed in the grain boundaries can cause intergranular corrosion and, in extreme cases, even a decrease in toughness [15]. However, after only short times in the critical temperature range, the risk of precipitation is very small for the low-carbon stainless steels.

In this work, super duplex stainless steel (SDSS) grade UNS S32760, which is one of the most superior upper duplex stainless steels, is considered. It has the chemical composition shown in Table 1, granting a high corrosion resistance, especially against pitting corrosion. This SDSS has higher tendency to precipitate intermetallic phases than other common duplex and austenitic stainless steels. This is due to the high $\mathrm{Cr}$ and Mo contents and high diffusion rates in the ferrite phase. In a previous research, microstructure variation and secondary phase precipitations were studied versus precipitation of UNS N08367 and UNS S42900 (super austenitic and ferritic stainless steels respectively). Secondary phases were identified by the microhardness and X-Ray Diffraction tests. An attempt to correlate between the type of phases versus toughness and corrosion resistance after aging was made.

The relation between the impact and corrosion behavior of solely phased stainless steels; austenitic UNS N08367 and ferritic UNS S42900 and the composite steel SDSS UNS 32760 was studied based on the composite rule of the mixtures (ROM). The ROM which is known as to enable the estimation of composite properties

Table 1. Chemical composition of the specimens, Fe = balance.

\begin{tabular}{|c|c|c|c|c|c|c|c|c|c|c|c|c|}
\hline Element [\%] & & $\mathrm{C}$ & $\mathrm{Si}$ & $\mathrm{Mn}$ & $\mathrm{P}$ & $\mathrm{S}$ & $\mathrm{Cr}$ & $\mathrm{Ni}$ & Mo & $\mathrm{Cu}$ & W & $\mathrm{N}$ \\
\hline \multirow[t]{2}{*}{$\begin{array}{l}\text { Composite SDSS } \\
\text { UNS S32760 }\end{array}$} & $\begin{array}{c}\text { Standard } \\
\text { ASTM A240 }\end{array}$ & 0.03 & 1 & 1 & 0.03 & 0.01 & $24-26$ & $6-8$ & $3-4$ & $0.5-1$ & $0.5-1$ & 0.3 \\
\hline & Feedstock & 0.013 & 0.58 & 0.66 & 0.016 & 0.01 & 26 & 7 & 3.8 & 0.93 & 0.6 & $0.2-0.3$ \\
\hline \multirow[t]{2}{*}{$\begin{array}{c}\gamma \text { austenite constituent } \\
\text { SASS UNS N08367 }\end{array}$} & $\begin{array}{c}\text { Standard } \\
\text { ASTM A240 }\end{array}$ & 0.03 & 1 & 2 & 0.04 & 0.03 & $20-22$ & $23.5-25.5$ & $6-7$ & 0.75 & - & $0.18-0.25$ \\
\hline & Feedstock & 0.02 & 0.35 & 0.86 & 0.014 & 0.03 & 21.5 & 25.3 & 6.1 & 0.7 & - & 0.2 \\
\hline \multirow[t]{2}{*}{$\begin{array}{c}\alpha \text { ferrite constituent } \\
\text { FSS UNS S42900 }\end{array}$} & $\begin{array}{c}\text { Standard } \\
\text { ASTM A240 }\end{array}$ & 0.12 & 1 & 1 & 0.04 & 0.03 & $14-16$ & - & - & - & - & - \\
\hline & Feedstock & 0.009 & 0.2 & 0.2 & 0.02 & 0.001 & 15.7 & - & - & - & - & - \\
\hline
\end{tabular}


in terms of its constituent's properties and their volume fractions ROM and its modifications due to microstructural considerations has been approved for mechanical properties but also for some other physical properties such as electrical and thermal ones.

\section{Methodology}

SDSS UNS S32760 is considered as a composite material, which is formed from two prime phases (constituents); the $\gamma$ austenite and $\alpha$ ferrite. The $\gamma$ austenite is the solely primary phase in the super austenitic stainless steel (SASS) UNS N08367, while $\alpha$ ferrite is solely primary phase in the ferritic stainless steel (FSS) UNS S42900.ROM is applied to model the SDSS properties.

\section{Experimental Work}

\subsection{Material}

The standard (ASTM) and feedstock's chemical analyses, of the composite SDSS UNS S32760 steel and the constituent's, SASS UNS N08367 $\gamma$ and FSS UNS S42900 $\alpha$ steels are given in Table 1 . The feedstock dimensions are $50 \times 40 \times 15 \mathrm{~mm}$.

\subsection{Heat Treatment}

Two heat treatments with different targets were subsequently applied on the feedstock specimens, as follows:

1) Solution annealing, is mandatory to dissolve any retained secondary precipitates and to relieve any residual thermal stress in the feedstock specimens. It is used, for the purpose to measure toughness and corrosion weight (CWL) on samples with solely primary $\gamma$ austenite or $\alpha$ ferrite phases without any secondary precipitates. Solution annealing was performed for the feedstock specimens of the SDSS UNS S32760 and SASS UNS N08367 materials, as per materials specification ASTM A240 [2]. In case of FSS ASTM A240, the feedstock is supplied in the annealed conditions, as mill's final treatment for the ferrite stainless [2].

2) Isothermal heat treatment is conducted to precipitate the secondary precipitates at their formation temperature ranges. This is for the purpose to test toughness and weight loss corrosion test on composite SDSS and constituent's SASS and FSS samples with secondary precipitates. The isothermal heat treatment was conducted on specimens cut from the feedstock pieces, after their solution annealing with size of $2.5 \times 10 \times 5 \mathrm{~mm}$.

The Isothermal heat treatment of the composite SDDS was conducted, at a low temperature range of $350^{\circ} \mathrm{C}$ $500^{\circ} \mathrm{C}$ ( $\alpha$ ferrite transformation) and at a high range of $700^{\circ} \mathrm{C}-950^{\circ} \mathrm{C}$ ( $\gamma$ austenite transformation), as shown in Table 2. This is for the formation of secondary precipitates at the ferrite and austenitic transformation zones respectively. The treated samples are named hereafter as SDSS $_{-\mathbf{F}}$ and SDSS $_{-\mathrm{A}}$, respectively as indicated in Table 2. Similarly, the specimens of FSS and SASS constituent' steels, were also isothermally heat treated for the formation of secondary precipitates at the lower and higher temperature ranges as shown in Table 3 and Table 4, respectively. Based on TTT diagrams of the austenitic and ferritic steels [18] [19], a scheme for the isothermal

\begin{tabular}{|c|c|c|c|c|c|}
\hline Specimen No. & Temperature $\left({ }^{\circ} \mathrm{C}\right)$ & Time (min) & Specimen No. & Temperature $\left({ }^{\circ} \mathrm{C}\right)$ & Time (min) \\
\hline \multicolumn{3}{|c|}{ SDSS-F (ferrite temperature range) } & \multicolumn{3}{|c|}{ SDSS-A (austenitic temperature range) } \\
\hline 10 & 350 & 116.0 & 2 & 700 & 1.7 \\
\hline 11 & 350 & 166.0 & 6 & 700 & 3.3 \\
\hline 12 & 350 & 333.0 & 7 & 700 & 4.7 \\
\hline 8 & 430 & 45.0 & 16 & 860 & 0.7 \\
\hline 1 & 430 & 55.0 & 17 & 860 & 0.8 \\
\hline 9 & 430 & 67.0 & 18 & 860 & 1.0 \\
\hline 13 & 500 & 59.0 & 3 & 950 & 1.7 \\
\hline 14 & 500 & 75.0 & 4 & 950 & 2.5 \\
\hline 15 & 500 & 92.0 & 5 & 950 & 3.3 \\
\hline
\end{tabular}


Table 3. SDSS isothermal heat treatment conditions.

\begin{tabular}{ccc}
\hline Specimen No. & Temp $\left({ }^{\circ} \mathrm{C}\right)$ & Time $(\mathrm{min})$ \\
\hline 1 & 350 & 5.0 \\
2 & 350 & 60.0 \\
3 & 350 & 180.0 \\
4 & 350 & 600.0 \\
5 & 475 & 5.0 \\
6 & 475 & 60.0 \\
7 & 475 & 180.0 \\
8 & 475 & 600.0 \\
9 & 550 & 5.0 \\
10 & 550 & 60.0 \\
11 & 550 & 180.0 \\
12 & 550 & 600.0 \\
\hline
\end{tabular}

Table 4. SASS isothermal heat treatment conditions.

\begin{tabular}{ccc}
\hline Specimen No. & Temp $\left({ }^{\circ} \mathrm{C}\right)$ & Time $(\mathrm{min})$ \\
\hline 2 & 750 & 100.0 \\
3 & 750 & 300.0 \\
4 & 750 & 700.0 \\
5 & 860 & 70.0 \\
6 & 860 & 200.0 \\
7 & 860 & 500.0 \\
8 & 925 & 100.0 \\
9 & 925 & 300.0 \\
10 & 925 & 700.0 \\
\hline
\end{tabular}

heat treatment conditions applied on the composite and the two constituent's steels is shown in Figure 1.

\subsection{Tests}

Impact toughness of the notched specimens with a cross section $\left(2.5910 \mathrm{~mm}^{2}\right)$ was conducted according to ASTM A370. Corrosion weight loss test was conducted by use of ferric chloride solution according to ASTM G48 [20].

\section{Results and Discussion}

\subsection{Measured Impact Toughness and Corrosion Wight Loss}

Specimens of solution annealed and isothermal heat treated SDSS composite and both FSS and SASS constituent's steels have been tested for the impact toughness (according to ASTM A370) and specific weight loss corrosion (according to ASTM G48 practice A). This is given in Table 5 and Table 6 for solution annealed and isothermally heat treated specimens respectively.

\subsection{Modeling of SDSS Properties Applying ROM}

In this work, ROM is applied to model the impact toughness of SDSS UNS S32760 as a composite including 


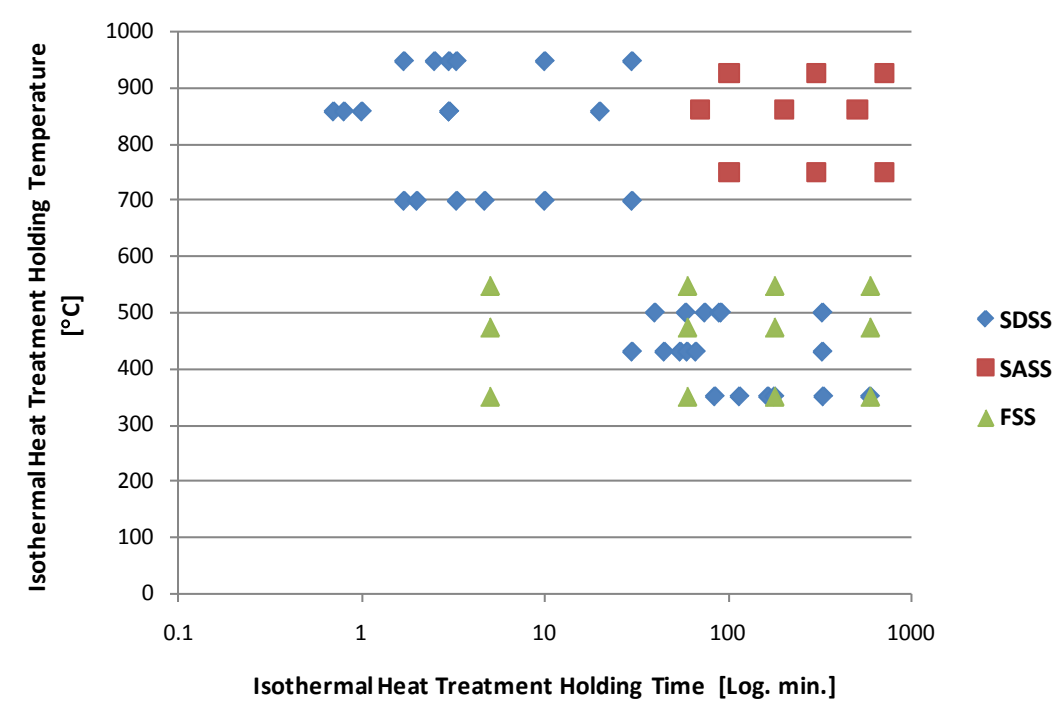

Figure 1. Isothmeral heat treatment scheme for SDSS, FSS and SASS.

Table 5. Measured toughness and corrosion specific weight loss (CWL) of solution annealed SDSS, FSS and SASS.

\begin{tabular}{ccccc}
\hline No. & Steel & Heat treatment & Toughness $(\mathrm{J})$ & CWL $\left(\mathrm{mg} / \mathrm{cm}^{2}\right)$ \\
\hline 19 & SDSS & Ferrite temperature range-SDSS & Time $=1$ min \\
& & Austenitic temperature range-SDSS-A & 23.0 & 0.0169 \\
19 & SDSS & Time $=1$ min & 23.0 & 0.0169 \\
13 & FSS & Ferrite temperature range (as received) & 21.0 & 11.7252 \\
1 & SASS & Austenitic temperature range & 25.0 & 0.0000 \\
\hline
\end{tabular}

$\gamma$-austenite and $\alpha$-ferrite as constituent phases. A trial is also made to use it for estimating the specific weight loss corrosion.

Since the volume fraction of each of the constituent's $\gamma$-austenite and $\alpha$-ferrite phases in SDSS is $0.50 \%$, then the basic ROM for the relationship between the composite SDSS property and the constituents $\alpha$-ferrite and $\gamma$-austenite phases, can be described by the following equation:

$$
\text { Property }_{\text {SDSS }}=0.5 \times\left(\text { Prperty }_{\mathrm{FSS}}+\text { Property }_{\mathrm{SASS}}\right)
$$

In this equation, FSS and SASS denote the constituent's FSSUNS S42900 and SASSUNS N08367, respectively. The properties obtained from testing both steels under similar heat treatment conditions as for the composite steel SDSS UNS S32760 are considered representing $\alpha$-ferrite and $\gamma$-austenite phases in the composite steel respectively. In Equation (1), "Property" denotes either toughness or weight loss corrosion. This is considered for three heat treatment conditions on SDSS composite and FSS and SASS constituent's steel. These correspond to solution annealing, similar isothermal heat treatment and different isothermal heat treatment with similar secondary precipitates.

\subsubsection{Case of Solution Annealing (SA)}

As shown in Figure 2, the microstructure obtained in the solution annealed (SA) SDSS is composed of primary austenite $\gamma$ and primary ferrite $\alpha$ (ferrite matrix is darker), without any secondary precipitate [21].

In this case, ROM for calculating toughness is written as follows:

$$
\text { Toughness } \mathrm{SDSS}_{\mathrm{SA}}^{\mathrm{SA}}=0.5 \times\left(\text { Toughness }_{\mathrm{FSS}}^{\mathrm{SA}}+\text { Toughness }_{\mathrm{SASS}}^{\mathrm{SA}}\right)
$$

In the solution annealing conditions (SA), the measured toughness values of FSS and SASS are $21 \mathrm{~J}$ and $25 \mathrm{~J}$ 


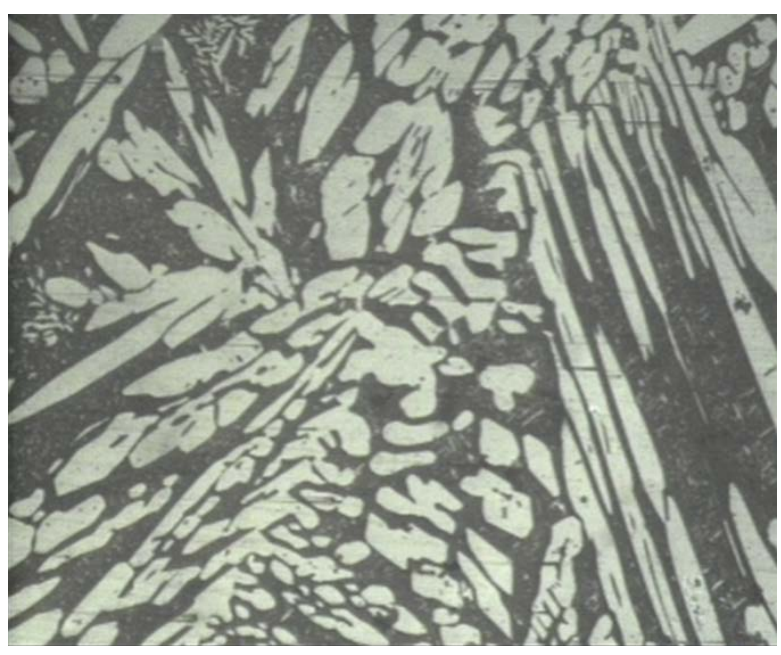

Figure 2. Composite structure obtained for SDSS UN 32760 ingots after solution annealing, showing $\gamma$ and $\alpha$ phases with absence of any secondary precipitates.

Table 6. Measured impact toughnessand corrosion specific weight loss (CWL) of SDSS thermally treated on different specimen with different temperatures $(\mathrm{T})$ and time (t).

\begin{tabular}{|c|c|c|c|c|c|c|c|c|c|}
\hline No. & $\mathrm{T}\left({ }^{\circ} \mathrm{C}\right)$ & $\mathrm{t}(\mathrm{min})$ & Toughness (J) & $\mathrm{CWL}\left(\mathrm{mg} / \mathrm{cm}^{2}\right)$ & No. & $\mathrm{T}\left({ }^{\circ} \mathrm{C}\right)$ & $\mathrm{t}(\min )$ & Toughness (J) & $\mathrm{CWL}\left(\mathrm{mg} / \mathrm{cm}^{2}\right)$ \\
\hline \multicolumn{5}{|c|}{ SDSS-A (austenitic temperature range) } & \multicolumn{5}{|c|}{ SDSS-F (ferrite temperature range) } \\
\hline 2 & 700 & 1.7 & 31.0 & 0.2769 & 10 & 350 & 116.0 & 16.0 & 0.1874 \\
\hline 6 & 700 & 3.3 & 17 & 0.0153 & 11 & 350 & 166.0 & 20.0 & 0.3561 \\
\hline 7 & 700 & 4.7 & 19.0 & 0.3939 & 12 & 350 & 333.0 & 27.0 & 0.1524 \\
\hline 16 & 860 & 0.7 & 22.0 & 0.1051 & 8 & 430 & 45.0 & 18.0 & 0.1218 \\
\hline 17 & 860 & 0.8 & 13.0 & 1.3540 & 1 & 430 & 55.0 & 18.0 & 0.0927 \\
\hline 18 & 860 & 1.0 & 13.0 & 0.9637 & 9 & 430 & 67.0 & 6.0 & 0.0153 \\
\hline 3 & 950 & 1.7 & 23.0 & 0.0000 & 13 & 500 & 59.0 & 27.0 & 0.0751 \\
\hline 4 & 950 & 2.5 & 14.0 & 0.0600 & 14 & 500 & 75.0 & 13.0 & 9.0932 \\
\hline 5 & 950 & 3.3 & 7.0 & 0.0326 & 15 & 500 & 92.0 & 22.0 & 2.4988 \\
\hline \multicolumn{5}{|c|}{ SASS (austenitic temperature range) } & \multicolumn{5}{|c|}{ FSS (ferrite temperature range) } \\
\hline 2 & 750 & 100.0 & 24.0 & 0.1822 & 1 & 350 & 5.0 & 21.0 & 29.9938 \\
\hline 3 & 750 & 300.0 & 25.0 & 0.0267 & 2 & 350 & 60.0 & 21.3 & 10.0257 \\
\hline 4 & 750 & 700.0 & 24.0 & 0.2353 & 3 & 350 & 180.0 & 20.0 & 13.4866 \\
\hline 5 & 860 & 70.0 & 22.0 & 0.0391 & 4 & 350 & 600.0 & 20.6 & 7.3370 \\
\hline 6 & 860 & 200.0 & 17.0 & 0.0000 & 5 & 475 & 5.0 & 22.3 & 28.8082 \\
\hline 7 & 860 & 500.0 & 12.0 & 0.3535 & 6 & 475 & 60.0 & 22.0 & 16.7761 \\
\hline 8 & 925 & 100.0 & 16.0 & 0.0133 & 7 & 475 & 180.0 & 22.0 & 10.6719 \\
\hline 9 & 925 & 300.0 & 10.0 & 0.0363 & 8 & 475 & 600.0 & 21.6 & 12.8679 \\
\hline 10 & 925 & 700.0 & 7.0 & 0.0411 & 9 & 550 & 5.0 & 21.3 & 12.5479 \\
\hline- & - & - & - & - & 10 & 550 & 60.0 & 24.0 & 6.7079 \\
\hline- & - & - & - & - & 11 & 550 & 180.0 & 26.0 & 7.8159 \\
\hline- & - & - & - & - & 12 & 550 & 600.0 & 24.0 & 11.9562 \\
\hline
\end{tabular}


respectively (Table 5). These are used in Equation (2) where the calculated toughness of as-annealed SDSS composite, is found similar to the experimentally measured value of $23 \mathrm{~J}$ (Table 5). Thus the basic ROM is found to describe the measured toughness data in SA case, where there are no secondary phase precipitates in composite and constituent's steels.

\subsubsection{Case of Isothermal Heat Treatment (IT)}

Table 7 shows the main secondary precipitations detected in SDSS, UNS N08367 which was isothermally treated within the lower $350^{\circ} \mathrm{C}-500^{\circ} \mathrm{C}$, and higher $700^{\circ} \mathrm{C}-950^{\circ} \mathrm{C}$ temperature ranges for $\alpha$-ferrite $\gamma$-austenite transformations respectively. In order to investigate the impact of these phases on the toughness and corrosion, two concepts are used for applying ROM. First; considering the composite and constituent's steels as subjected to similar heat treatment conditions. This is although that in the case of isothermally heat treated samples, the composite and constituent's steels may differ in their secondary precipitations. Secondly, considering the composite and constituents steels having similar secondary precipitates after any heat treatment.

\section{First Concept: Similar Isothermal Heat Treatment}

In this case, ROM is applied considering composite and constituent's steels as subjected to similar heat treatment conditions, where the secondary precipitates may be different. The role of each precipitation group at low and high temperature transformation ranges is investigated.

\section{Toughness}

The role of precipitation group at the austenitic transformation range is investigated based on calculating toughness of SDSS which is subjected to isothermal treatment within the austenitic higher temperature range

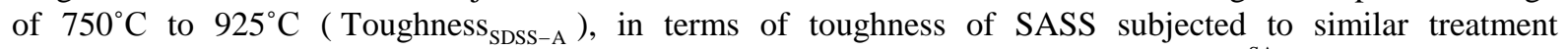
( Toughness $_{\mathrm{SASS}}$ ), while the toughness of FSS is that of the solution annealed (ToughnesS $\mathrm{FSS}_{\mathrm{SA}}^{\mathrm{SA}}$ ). This is expressed as follows:

$$
\text { Toughness }_{\mathrm{SDSS}-\mathrm{A}}=0.5 \times\left(\text { Toughness }_{\mathrm{SASS}}+\text { Toughness }_{\mathrm{FSS}}^{\mathrm{SA}}\right)
$$

The experimental and calculated values are listed in Table 8, while they are represented for different heat treatment temperatures in Figure 3. The trend is that toughness decreases with increasing temperature, while both experimental and calculated data at any temperature are generally found within the same range. Calculated toughness is found to be $30 \%$ higher than the experimentally measured value. It is to be noticed that application of ROM ignored the detrimental effect of each of the formed secondary precipitate which may differ from each other as well as their variation in the similarly treated composite and constituent's steels. The $\sigma$ phase and which forms at $700^{\circ} \mathrm{C}-950^{\circ} \mathrm{C}$ upper temperature range is very harmful to toughness [15] [21]. With increasing isothermal treatment temperature and time, formation of $\sigma$ phase is associated with $\chi$-phase formation [21], which is even most harmful.Carbide and nitride precipitates occur in the temperature range $550^{\circ} \mathrm{C}-800^{\circ} \mathrm{C}$ which are also harmful to toughness. Thus the decrease of toughness with temperature increase could be explained.

However, toughness should be considered as a function of isothermal heat treatment parameters; namely temperature and holding time. This could be represented by a polynomial function of the second degree correlating the toughness with temperature and time as represented by the following equation:

$$
\text { Toughness }=a \times x^{2}+b \times x \times y+c \times y^{2}+d \times x+e \times y+f
$$

where, $x$ : temperature (in ${ }^{\circ} \mathrm{C}$ ) $y$ : time (in $\left.\min \right) a, b, c, d, e$ and $f$ are constants.

\begin{tabular}{|c|c|c|c|}
\hline $\begin{array}{c}\text { Primary Phase Transformation } \\
\text { Zone }\end{array}$ & Formation Temperature $\left({ }^{\circ} \mathrm{C}\right)$ & Detected Phase & Average Microhardness (HV) \\
\hline \multirow{3}{*}{$\begin{array}{c}\gamma \text {-austenite } \\
700^{\circ} \mathrm{C}-950^{\circ} \mathrm{C}\end{array}$} & $700-950$ & $\sigma$-phase & $664-674$ \\
\hline & $700-950$ & $\sigma+\gamma_{2}$-phases & - \\
\hline & 700 & $\sigma$, iron nitrides and carbide phases & 1080 \\
\hline$\alpha$-ferrite & 350 & $\dot{\alpha}$ & 298 \\
\hline $350^{\circ} \mathrm{C}-500^{\circ} \mathrm{C}$ & $350-500$ & Aged $\alpha$ & 372 \\
\hline
\end{tabular}

Table 7. Main secondary precipitates detected in IT samples of SDSS. 


\begin{tabular}{cccc|}
\hline \multicolumn{5}{l}{ Table 8. Experimental and calculated } & Toughness $_{\text {SDSS-A }}$. \\
\hline No. & $\begin{array}{c}\text { Isothermal Treatment } \\
\text { Temperature, } \\
{\left[{ }^{\circ} \mathrm{C}\right]}\end{array}$ & $\begin{array}{c}\text { Experimental } \\
\text { Toughness }_{\text {sDss-A }}\end{array}$ & $\begin{array}{c}\text { Calculated } \\
\text { Toughness }_{\text {sDss-A }} \\
{[\mathrm{J}]}\end{array}$ \\
\hline 6 & 700 & 17 & 23.0 \\
7 & 700 & 19.0 & 22.5 \\
17 & 860 & 13.0 & 19.0 \\
18 & 860 & 13.0 & 16.5 \\
4 & 950 & 14.0 & 15.5 \\
5 & 950 & 7.0 & 14.0 \\
\hline
\end{tabular}

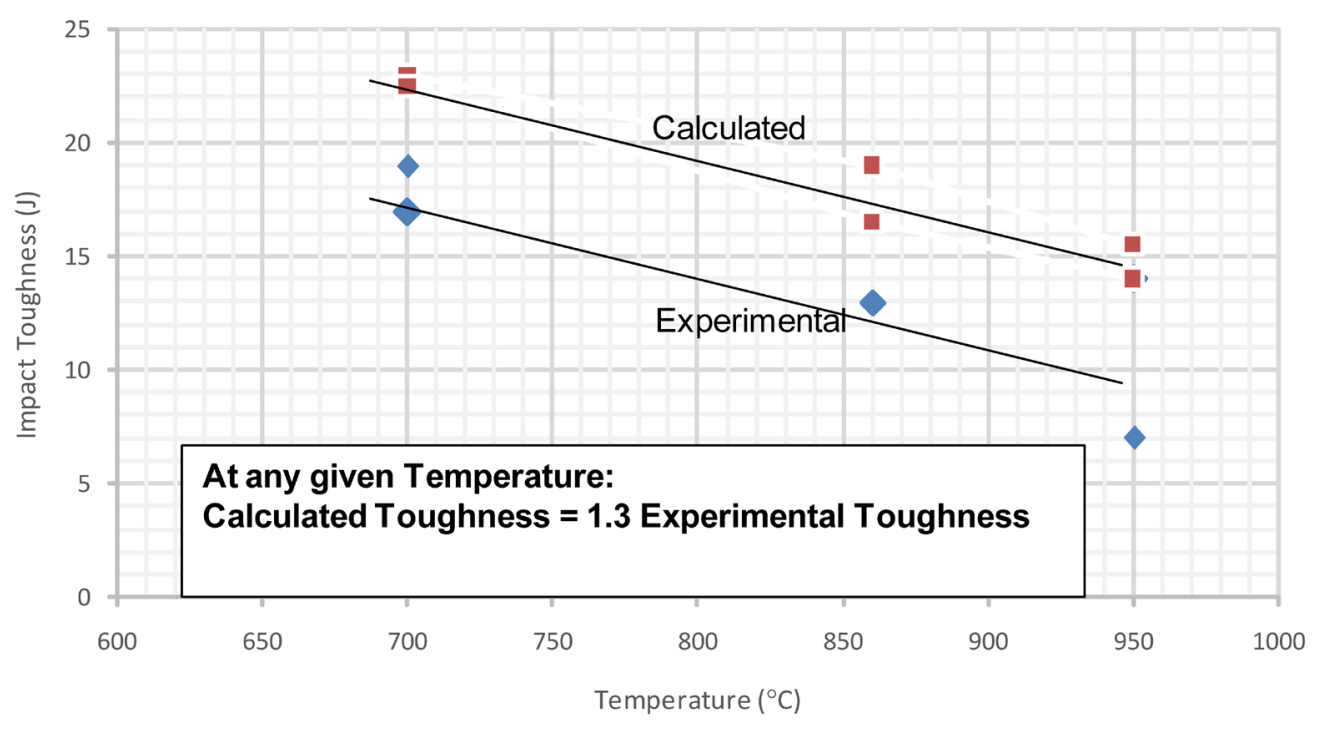

Figure 3. Calculated and experimental Toughness SDss-A $_{\text {a }}$ at austenitic high temperature (isotherml treatmnt times in min. is indicated between brackets).

The curve fitting process can be carried out to describe both the experimental and model results. Different fitting functions (power, trigonometric and polynomial) are tried and a polynomial function of the second degree is found to be fair for reaching a high regression of more than $97 \%$. This is shown in Figure 4, which presents the case of SDSS $_{\mathrm{A}}$, where the experimental (a) and model data (b) data for Toughness SDss-A $_{\text {A }}$ as well as the deviation \% between them (c) are indicated. It is remarkable that each of the plotted curves follows a C-curve similar to the TTT diagram. This is taken as indication that toughness values are affected by the formation of secondary precipitations. At isothermal treatment conditions of $700^{\circ} \mathrm{C}$ and long holding times, Figure 4(a) and Figure 4(b),

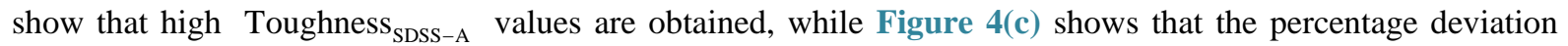
between the experimental and calculated results in this case is small.

The role of precipitation group at the ferritic transformation range is investigated based on calculating toughness of SDSS which is subjected to isothermal treatment within the ferrite lower temperature range of 350 to $500^{\circ} \mathrm{C}$ ( Toughness $_{\mathrm{SDSS}-\mathrm{F}}$ ), in terms of toughness of FSS subjected to similar treatment ( Toughness $_{\mathrm{FSS}}$ ), while the toughness of SASS is that for solution annealing (Toughness ${ }_{\text {SASS }}^{\text {SA }}$ ). This is expressed as follows:

$$
\text { Toughness }_{\text {SDSS-F }}=0.5 \times\left(\text { Toughness }_{\mathrm{FSS}}+\text { Toughness }_{\mathrm{SASS}}^{\mathrm{SA}}\right)
$$

The experimental and calculated values are listed in Table 9, while they are represented for different heat treatment temperatures in Figure 5. The trend is that toughness remains almost constant with increasing temperature, while both experimental and calculated toughness data at any temperature are generally found within 

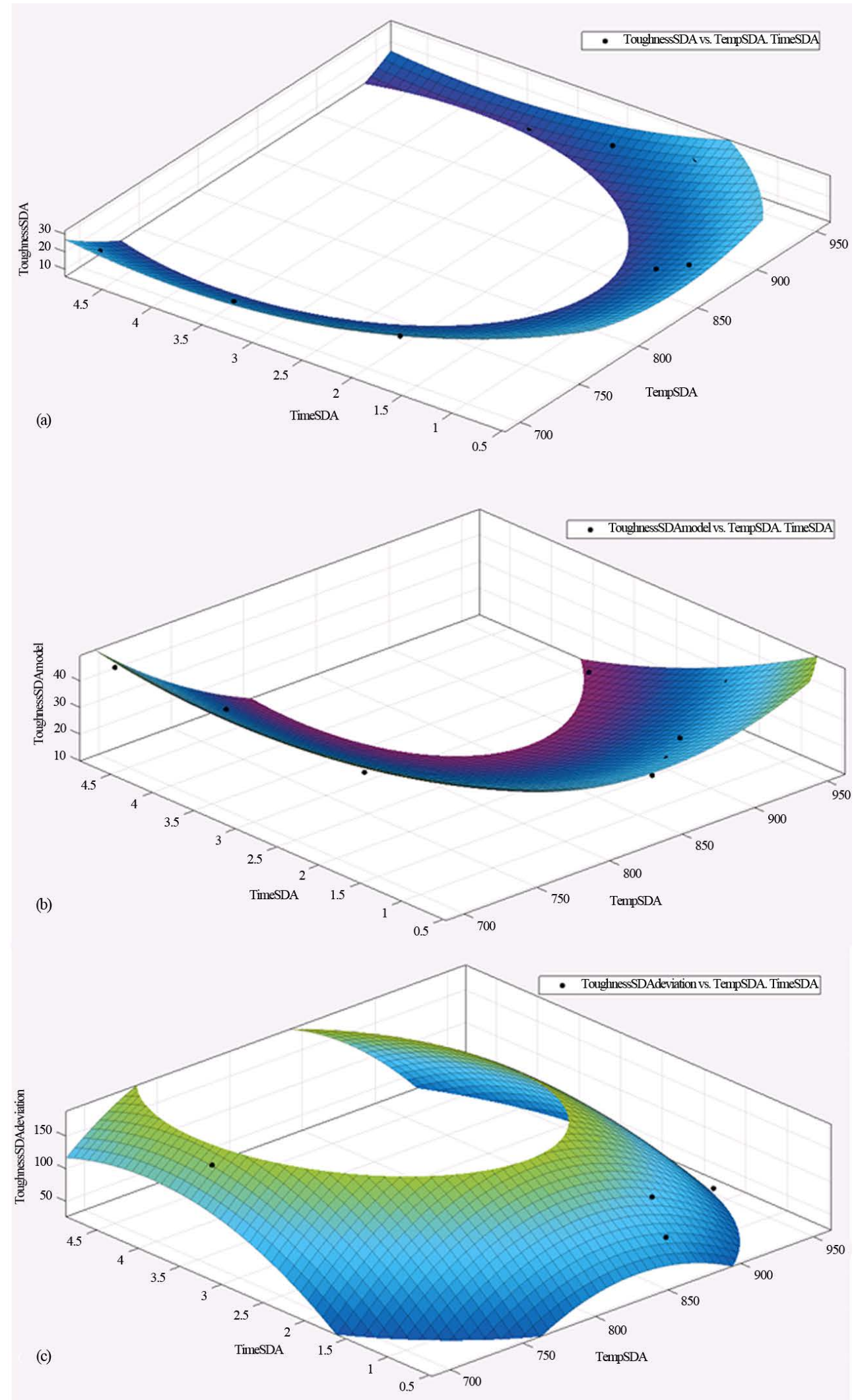

Figure 4. Second degree curve fitting for (a) experimental Toughness SDSs-A $_{-}$(b) modelled Toughness SDSs-A $_{\text {A }}$ (c) deviation\% between the model and the experimental results. 
Table 9. Experiment and calculated Toughness $_{\text {SDss-F }}$.

\begin{tabular}{cccc}
\hline No. & $\begin{array}{c}\text { Isothermal Treatment } \\
\text { Temperature, } \\
{\left[{ }^{\circ} \mathrm{C}\right]}\end{array}$ & $\begin{array}{c}\text { Experimental } \\
\text { Toughness }_{\text {sDss-F }}\end{array}$ & $\begin{array}{c}\text { Calculated } \\
\text { Toughness }_{\text {sDs-F }} \\
{[\mathrm{J}]}\end{array}$ \\
\hline 10 & 350 & 16.0 & 23.0 \\
11 & 350 & 20.0 & 22.5 \\
8 & 430 & 18.0 & 23.7 \\
9 & 430 & 18 & 23.5 \\
14 & 500 & 13.0 & 24.5 \\
15 & 500 & 22.0 & 23.2 \\
\hline
\end{tabular}

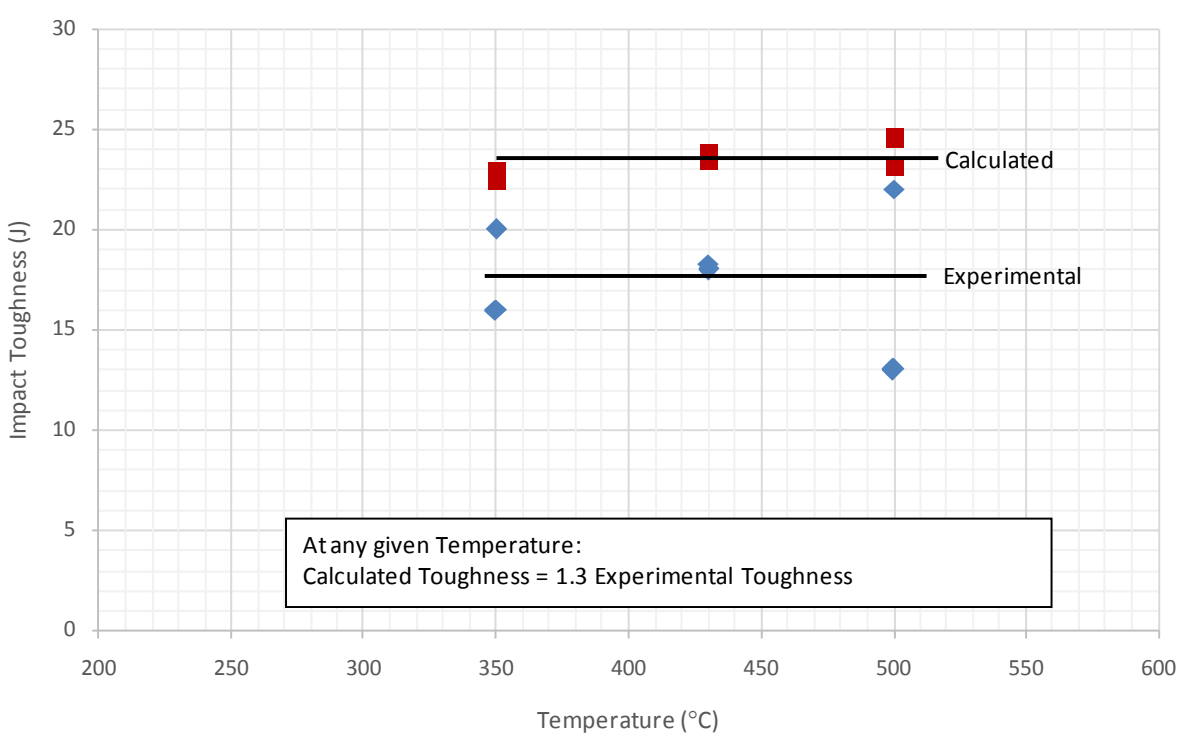

Figure 5. Calculated and experimental Toughness SDss-A $_{\text {a }}$ at ferrite low temperature (isother$\mathrm{ml}$ treatmnt times in min. is indicated between brackets).

similar range. Calculated Toughness is found to be $30 \%$ higher than the experimentally measured value, similar to Toughness ${ }_{\mathrm{SDSS}-\mathrm{A}}$. It seems that the $\alpha^{\prime}$ and the associated aged $\alpha^{\prime}$, which form at $350^{\circ} \mathrm{C}-500^{\circ} \mathrm{C}$ low temperature range [15] [21], has similar harmful effect to Toughness ${ }_{\text {SDSS-F }}$ as Toughness ${ }_{\text {SDSS-A }}$, while it is difficult to separate their effect from each other.

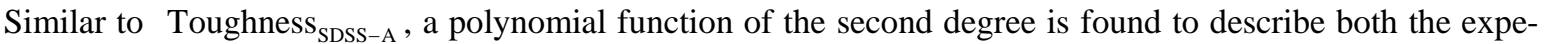
rimental and calculated results of Toughness SDSS-F as shown in Figure 6. Again it can be seen that a skewed C-curve, similar to that in the TTT diagram, is obviously remarkable. For the calculated results in Figure 6, the C-curve is not complete and is less detrimental.

\section{Corrosion}

ROM is also used to estimate corrosion weight loss (CWL) of SDSS in terms of the experimental values of SASS and FSS. CWL is considered, since more accurate results are obtained compared to potentiostatic testing method as reported in a previous work on UNS S32760, UNS N08367 and UNS S42900 steels [21]. Similar to toughens, ROM is applied to investigate the role of each of the austenitic and ferritic precipitation groups separately.

The role of precipitation group at the austenitic transformation range is investigated, based on calculating CWL of SDSS which is subjected to isothermal treatment within the austenitic higher temperature range of 750 to $925^{\circ} \mathrm{C}\left(\mathrm{CWL}_{\mathrm{SDSS}-\mathrm{A}}\right)$, in terms of CWL of SASS subjected to similar isothermal treatment $\left(\mathrm{CWL}_{\mathrm{SASS}}\right)$, while the CWL of FSS is that of the as received( $\mathrm{CWL}_{\mathrm{FSS}}^{\mathrm{SA}}$ ). This is expressed as follows: 


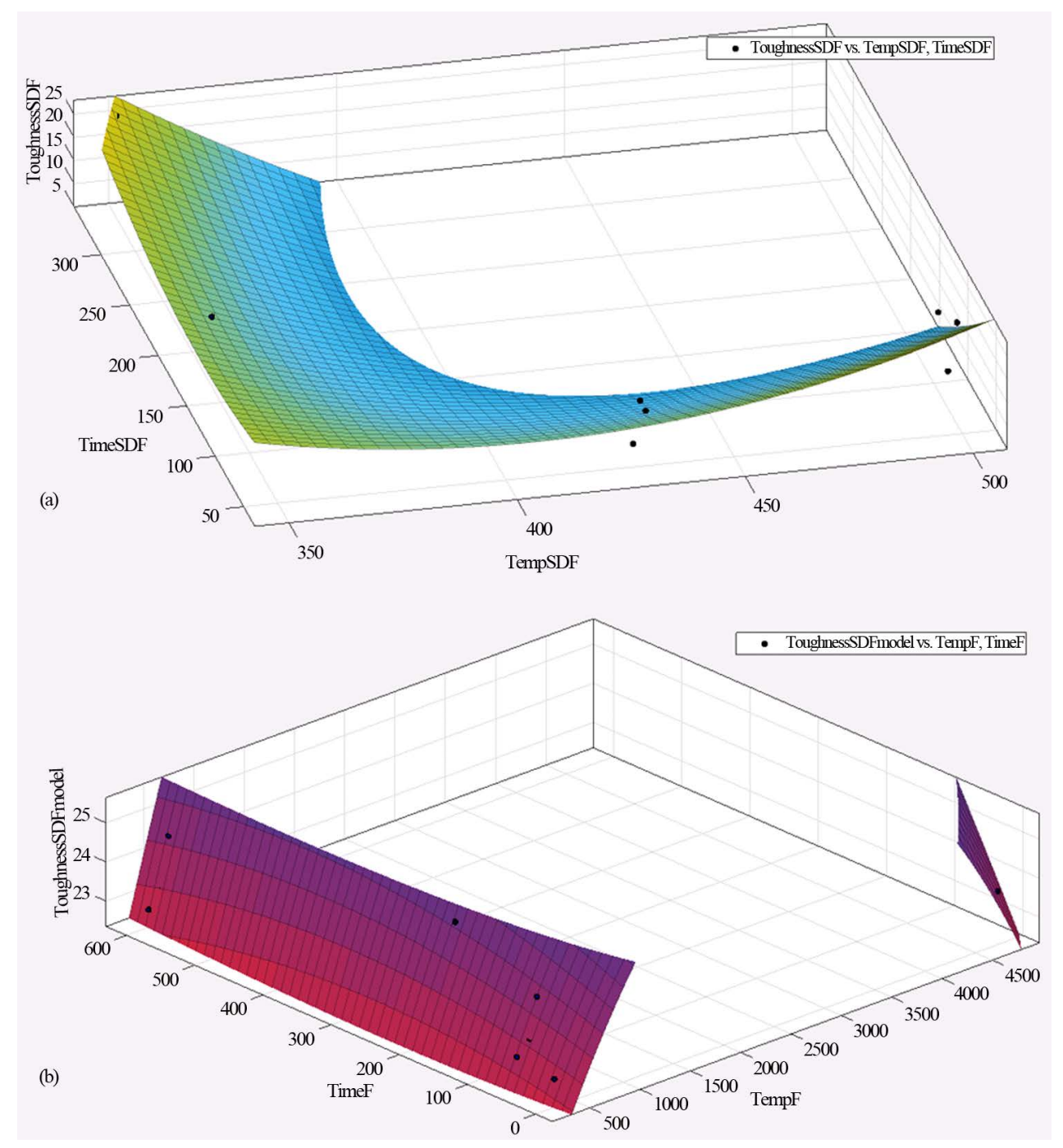

Figure 6. Second degree curve fitting for (a) experimental Toughness SDSS-F- $^{-}$(b) modelled Toughness SDSS-F- $^{-}$ (c) deviation\% between the model and the experimental results.

$$
\mathrm{CWL}_{\mathrm{SDSS}-\mathrm{A}}=0.5 \times\left(\mathrm{CWL}_{\mathrm{SASS}}+\mathrm{CWL}_{\mathrm{FSS}}^{\mathrm{SA}}\right)
$$

The role of precipitation group at the ferritic transformation range is investigated, based on calculating corrosion CWL of SDSS as isothermally treated within the ferrite transformation temperature range of $350{ }^{\circ} \mathrm{C}$ to $500^{\circ} \mathrm{C}\left(\mathrm{CWL}_{\mathrm{SDSS}-\mathrm{F}}\right)$, in term of CWL of FSS subjected to similar treatment $\left(\mathrm{CWL}_{\mathrm{FSS}}\right)$, while CWL of SASS is that of solution annealing ( $\mathrm{CWL}_{\mathrm{SASS}}^{\mathrm{SA}}$ ). This is expressed as follows:

$$
\mathrm{CWL}_{\mathrm{SDSS}-\mathrm{F}}=0.5 \times\left(\mathrm{CWL}_{\mathrm{FSS}}+\mathrm{CWL}_{\mathrm{SASS}}^{\mathrm{SA}}\right)
$$

Experimental and calculated CWL, using Equation (7) and Equation (8) for $\mathrm{CWL}_{\mathrm{SDSS}-\mathrm{A}}$ and $\mathrm{CWL}_{\mathrm{SDSS}-\mathrm{F}}$ are given in 10 and 11, respectively (Table 10, Table 11).

The data is presented as shown in Figure 7 and Figure 8, for the cases of $\mathrm{CWL}_{\mathrm{SDSS}-\mathrm{A}}$ and $\mathrm{CWL}_{\mathrm{SDSS}-\mathrm{F}}$ respectively. Experimental and calculated data are generally far from each other. Corrosion is a surface related phenomenon depending on the protective chromium oxide layer [1]. Precipitated secondary phase plays also a detrimental effect on corrosion behavior of such alloys [1] [2] [9] [10]-[15]. However, the deviation between of the experimental and calculated CWL is much decreased by values up to 50\% for isothermal treatment at or close to the nose of the austenitic and ferritic transformation ranges of $700^{\circ} \mathrm{C}-750^{\circ} \mathrm{C}$ and $480^{\circ} \mathrm{C}-500^{\circ} \mathrm{C}$, respectively. 
Table 10. Experimental and calculated $\mathrm{CWL}_{\mathrm{SDSS}-\mathrm{A}}$.

\begin{tabular}{cccc}
\hline No. & $\begin{array}{c}\text { Isothermal Treatment } \\
\text { Temperature, } \\
{\left[{ }^{\circ} \mathrm{C}\right]}\end{array}$ & $\begin{array}{c}\text { Experimental } \\
\mathrm{CWL}_{\text {sDss- }} \\
\left(\mathrm{mg} / \mathrm{cm}^{2}\right)\end{array}$ & $\begin{array}{c}\text { Calculated } \\
\mathrm{CWL}_{\text {sDss-A }} \\
\left(\mathrm{mg} / \mathrm{cm}^{2}\right)\end{array}$ \\
\hline 2 & 700 & 0.2769 & 0.1080 \\
6 & 700 & 0.0153 & 0.0303 \\
7 & 700 & 0.3939 & 0.1346 \\
16 & 860 & 0.1051 & 0.0364 \\
\hline
\end{tabular}

Table 11. Experimental and calculated $\mathrm{CWL}_{\mathrm{SDSS}-\mathrm{F}}$.

\begin{tabular}{cccc}
\hline No. & $\begin{array}{c}\text { Isothermal Treatment } \\
\text { Temperature, } \\
{\left[{ }^{\circ} \mathrm{C}\right]}\end{array}$ & $\begin{array}{c}\text { Experimental } \\
\mathrm{CWL}_{\text {sDss-F }} \\
\left(\mathrm{mg} / \mathrm{cm}^{2}\right)\end{array}$ & $\begin{array}{c}\text { Calculated } \\
\mathrm{CWL}_{\text {sDss-F }} \\
\left(\mathrm{mg} / \mathrm{cm}^{2}\right)\end{array}$ \\
\hline 10 & 350 & 0.1874 & 9.151218 \\
11 & 350 & 0.3561 & 0 \\
12 & 350 & 0.1524 & 0.897638 \\
8 & 430 & 0.1218 & 8.558423 \\
1 & 430 & 0.0927 & 2.542368 \\
9 & 430 & 0.0153 & 0 \\
13 & 500 & 0.0751 & 0.428288 \\
14 & 500 & 9.0932 & 0 \\
15 & 500 & 2.4988 & 0 \\
17 & 860 & 1.3540 & 0.0169 \\
18 & 860 & 0.9637 & 0.1937 \\
3 & 950 & 0.0000 & 0.0236 \\
4 & 950 & 0.0600 & 0.0350 \\
5 & 950 & 0.0326 & 0.0375 \\
\hline
\end{tabular}

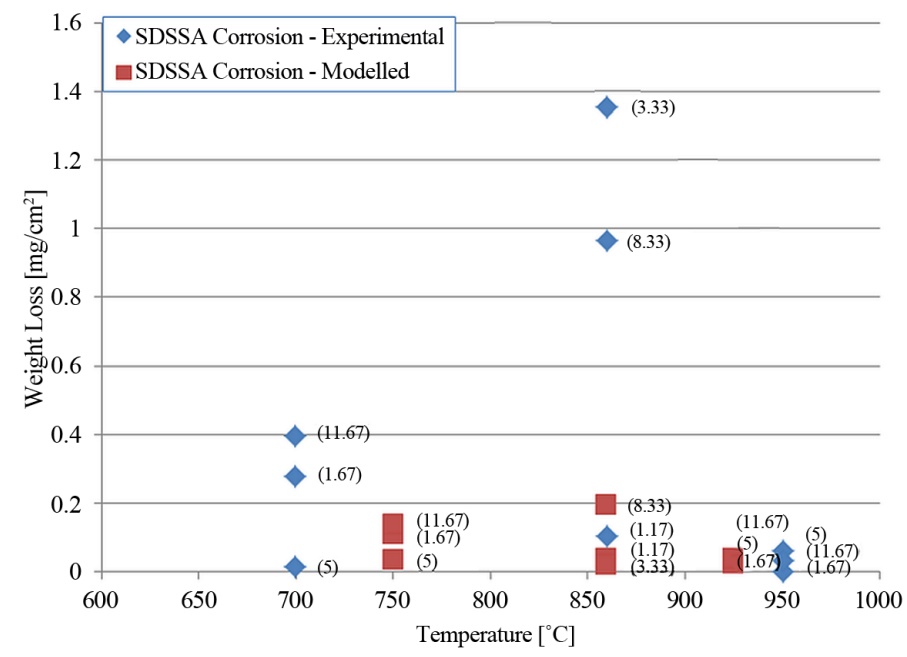

Figure 7. Comparison between the experimental and calculted $\mathrm{CWL}_{\mathrm{SDSS}-\mathrm{A}}$ (isotherml treatmnt times in min. is indicated between brackets). 


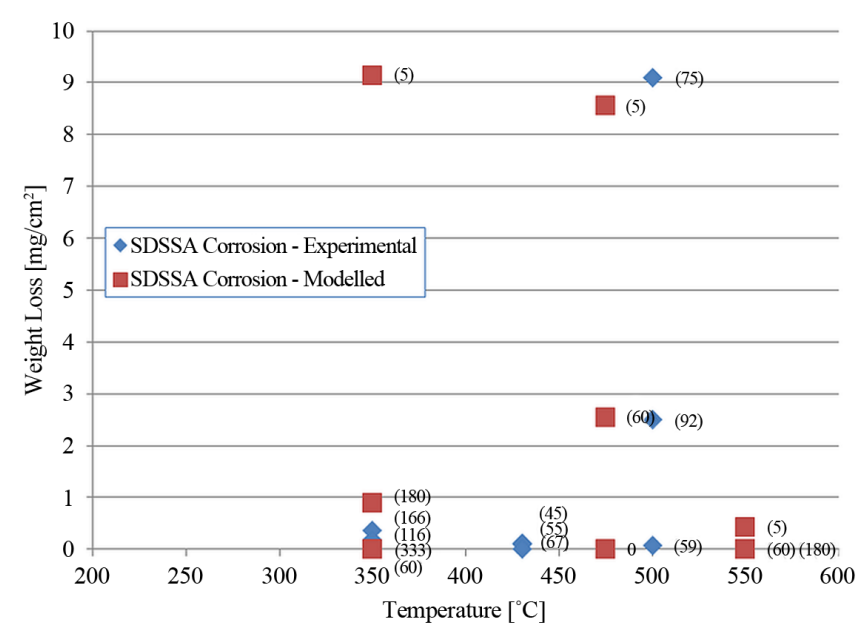

Figure 8. Comparison between the experimental and calculted $\mathrm{CWL}_{\mathrm{SDSS}-\mathrm{F}}$ (isotherml treatmnt times in min. is indicated between brackets).

It seems that the associated $\chi$ and the aged $\alpha$ ' phases are much more harmful to corrosion than the earlier formed $\sigma$ and $\alpha^{\prime}$ at each of the temperature ranges respectively. Moreover, although the volume fraction of the $\chi$-phase is not usually very high, it consumes significant amounts of $\mathrm{Cr}$ and Mo from the parent matrix, and the formed $\gamma_{2}$-phase becomes depleted of these elements. Hence, this usually decreases the pitting corrosion resistance [15] [21].

\section{Second Concept: similar secondary precipitates}

ROM is applied based on selection of samples of SDSS composite steel and SASS and FSS constituent's steels, with similar secondary precipitates in each of the primary austenite and ferrite phases. This is regardless of the isothermal heat treatment conditions conducted on each of these steels. This will help examining separately the influence of each group of secondary precipitates formed at lower and higher temperature transformation ranges, i.e. ferrite and austenitic transformation ranges respectively. ROM will consider the volume fraction (Vf) and toughness or CWL of each phase (property) as follows:

$$
\text { Property }_{\mathrm{SDSS}}=\left(\mathrm{Vf}_{\mathrm{SASS}} \cdot \text { Property }_{\mathrm{SASS}}+\mathrm{Vf}_{\mathrm{FSS}} \cdot \text { Property }_{\mathrm{SASS}}+\sum_{i=1}^{i=m} \mathrm{Vf}_{\text {Phase }(i)} \cdot \text { Property }_{\text {Phase }(i)}\right)
$$

Where; " $i$ " and " $j$ " are the numbers of phases at any heat treatment.

However, since it is difficult to measure the volume fraction of each of the secondary precipitates, ROM is applied considering secondary precipitates formed at each of austenitic or ferrite transformation zone as a group.

\section{Toughness}

ROM is used to calculate the toughness of SDSS composite after isothermal treatment within the austenitic transformation range in terms of toughness of SASS after similar treatment $\left(\mathrm{SASS}_{\mathrm{A}}\right)$ and the toughness of FSS in the annealed conditions (FSS annealed). This is in order to investigate separately the influence of secondary precipitates formed in $\gamma$-grains within this range. Table 12 gives an example of the results, in case of isothermal treatment at $860^{\circ} \mathrm{C}$ for $40 \mathrm{~s}$ and $200 \mathrm{~min}$; on SDSS and SASS samples respectively where the secondary precipitates formed in $\gamma$-phase grains are $\sigma$-phase, carbides and nitrides. The annealed FSS has $\alpha$-phase grains only without any secondary precipitates. The calculated $\mathrm{SDSS}_{\mathrm{A}}$ is found to be $17 \mathrm{~J}$, while the experimentally measured value is a higher value of $22 \mathrm{~J}$.

ROM is also used to calculate the toughness of SDSS composite after isothermal treatment within the ferrite transformation range $\left(\mathrm{SDSS}_{\mathrm{F}}\right)$ in terms of toughness of FSS after similar treatment $\left(\mathrm{FSS}_{\mathrm{F}}\right)$ and the toughness of

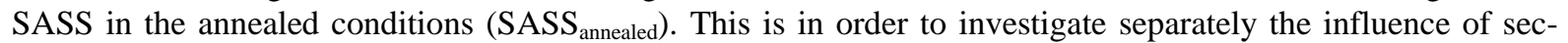
ondary precipitates formed in $\alpha$-grains within this range. Table 13, gives an example of the results, in case of isothermal treatment at $500^{\circ} \mathrm{C}$ for $59 \mathrm{~min}$ on SDSS and at $430^{\circ} \mathrm{C}$ for $5 \mathrm{~min}$ on FS, where $\alpha^{\prime}$ secondary precipitate is formed in $\alpha$-grains. The annealed SASS has $\gamma$-grains only without any secondary precipitate. The calculated SDSS $_{\mathrm{F}}$ is found to be $23.6 \mathrm{~J}$, while the experimentally measured value is a higher value of $27 \mathrm{~J}$.

It is to be noticed that the precipitates in the isothermally treated SASS, do not necessarily have the same size and volume fraction of the constituents steels subjected to the similar heat treatment temperature and time condi- 
Table 12. Calculated (ROM) and measured toughness and CWL of SDSS $_{\mathrm{A}}$.

\begin{tabular}{|c|c|c|c|c|}
\hline Specimen & $\begin{array}{l}\text { SASSA experimental } \\
\text { (specimen } 6 \text {, at } 860^{\circ} \mathrm{C} \text { for } \\
200 \mathrm{~min}\end{array}$ & $\begin{array}{c}\text { FSS annealed } \\
\text { experimental } \\
\text { (specimen } 13 \text {, annealed ) }\end{array}$ & $\begin{array}{l}\text { SDSSA experimental } \\
\text { (specimen } 16 \text {, heated at } \\
860^{\circ} \mathrm{C} \text { for } 40 \mathrm{~s} \text { ) }\end{array}$ & $\begin{array}{l}\text { SDSSA } \\
\text { calculated }\end{array}$ \\
\hline \multicolumn{5}{|l|}{ Microstructure } \\
\hline & $\begin{array}{l}\times 400 \text { equiaxed grains, } \\
\text { Secondary precipitates } \\
\text { Grain size differs }\end{array}$ & $\begin{array}{l}\times 400 \text { equiaxed grains, } \\
\text { No secondary precipitates } \\
\text { Grain size differs }\end{array}$ & $\begin{array}{l}\times 400 \text { Arrayed grains } \\
\text { Secondary precipitates } \\
\text { Grain size differs }\end{array}$ & \\
\hline Phases & $\begin{array}{l}\text { Grains: } \gamma \text {-phase, } \\
\text { Precipitates: } \sigma \text {-phase, } \\
\text { Carbides, nitrides }\end{array}$ & Grains: $\alpha$-phase, equiaxed & $\begin{array}{c}\text { Grains: } \gamma \text {-phase, } \alpha \text {-phase } \\
\text { Precipitates: } \sigma \text {-phase, } \\
\text { Carbides, nitrides in } \gamma \text { grains }\end{array}$ & \\
\hline $\begin{array}{l}\text { Toughness } \\
\text { (impact) }\end{array}$ & $=17 \mathrm{~J}$ & $=21 \mathrm{~J}$ & $=22 \mathrm{~J}$ & $\begin{array}{c}=0.5 \times(17+21) \\
=19 \mathrm{~J} \\
\text { with } 14 \% \text { deviation }\end{array}$ \\
\hline CWL & $=$ Zero $\mathrm{mg} / \mathrm{cm}^{2}$ & $11.7252 \mathrm{mg} / \mathrm{cm}^{2}$ & $0.1051 \mathrm{mg} / \mathrm{cm}^{2}$ & $\begin{array}{c}=0.5 \times(0+ \\
11.7252) \\
=5.8626 \mathrm{mg} / \mathrm{cm}^{2} \\
\text { with almost } 100 \% \\
\text { deviation }\end{array}$ \\
\hline
\end{tabular}

Table 13. Calculated (ROM) and measured toughness and CWL of SDSS ${ }_{\mathrm{F}}$.

\begin{tabular}{|c|c|c|c|c|}
\hline Specimen & $\begin{array}{c}\text { SASS } \\
\text { experimental } \\
\text { (specimen } 1 \text {, annealed) }\end{array}$ & $\begin{array}{c}\text { FSSF } \\
\text { experimental } \\
\text { (specimen } 5 \text { heated at } 430^{\circ} \mathrm{C} \text { for } \\
5 \text { min) }\end{array}$ & $\begin{array}{c}\text { SDSSF } \\
\text { experimental } \\
\text { (specimen } 13 \text {, heated at } 500^{\circ} \mathrm{C} \text { for } \\
59 \text { min) }\end{array}$ & $\begin{array}{c}\text { SDSSF } \\
\text { calculated }\end{array}$ \\
\hline Microstructure & $\begin{array}{l}\times 400 \text { equiaxed grains } \\
\text { No secondary precipitates } \\
\text { Grain size close }\end{array}$ & $\begin{array}{c}\text { ×400 equiaxed grains } \\
\text { Secondary precipitates } \\
\text { Grain size close }\end{array}$ & $\begin{array}{c}\times 200 \text { arrayed grains } \\
\text { Secondary precipitates } \\
\text { Grain size close }\end{array}$ & - \\
\hline Phases & Grains: $\gamma$-phase & $\begin{array}{c}\text { Grains: } \alpha \text {-phase } \\
\text { Precipitates: } \alpha \text {-phase }\end{array}$ & $\begin{array}{c}\text { Grains: } \gamma \text {-phase, } \alpha \text {-phase } \\
\text { Precipitates: } \alpha \text {-phase in } \alpha \text {-grains }\end{array}$ & - \\
\hline $\begin{array}{l}\text { Toughness } \\
\text { (impact) }\end{array}$ & $=25 \mathrm{~J}$ & $=22.3 \mathrm{~J}$ & $=27 \mathrm{~J}$ & $\begin{array}{c}=0.5 \times(25+22.3) \\
=23.6 \mathrm{~J} \\
\text { with } 12 \% \text { deviation }\end{array}$ \\
\hline CWL & $=$ Zero $\mathrm{mg} / \mathrm{cm}^{2}$ & $=28.8082 \mathrm{mg} / \mathrm{cm}^{2}$ & $0.0751 \mathrm{mg} / \mathrm{cm}^{2}$ & $\begin{array}{l}=0.5 \times(0+28.8082) \\
=14.4041 \mathrm{mg} / \mathrm{cm}^{2} \\
\text { with } 100 \% \text { deviation }\end{array}$ \\
\hline
\end{tabular}

tions. While the shape of $\gamma$ - and $\alpha$-grains are equiaxed in case of SASS- and SFSS-constituent's steels, it is in arrayed form in case of SASS. Such differences are not considered in ROM applied, which are reasons for the deviation between calculated and experimental results.

The calculated and measured toughness are more far from each other, in case of higher temperature isothermal treatment within the austenitic transformation range. This may indicate that the influence of $\sigma$-phase, carbides and nitrides formed in the $\gamma$-grains at this isothermal treatment is higher than the influence of $\alpha$-phase formed at the lower temperature range in the $\alpha$-grains. ROM applied considering the precipitates formed as a 
group, while the influence of each one is different. Previous report has reported that both $\sigma$-phase and $\alpha$, formed at austenitic and ferrite transformation ranges respectively, have drastic influence on toughness [1] [2] [9] [10]-[15].

\section{Corrosion}

The experimental and calculated corrosion data(CWL), of SDSS with similar secondary precipitates in each of the primary $\gamma$ - and $\alpha$-grainsin SASS and FSS respectively was obtained as indicated in Table 12 and Table 13 for austenitic and ferrite isothermal treatments respectively. Generally, the calculated and experimental CWL values are greatly far from each other with a deviation of more than $100 \%$. As an example, in Table 12, for $\mathrm{SDSS}_{\mathrm{A}}$, isothermal treated at $860^{\circ} \mathrm{C}$ for $40 \mathrm{~s}$, experimental CWL is $0.1051 \mathrm{mg} / \mathrm{cm}^{2}$, while the calculated CWL is much higher with value of $5.8626 \mathrm{mg} / \mathrm{cm}^{2}$. An example is given in Table 13, for SDSS $_{\mathrm{F}}$, isothermally treated at $500^{\circ} \mathrm{C}$ for $59 \mathrm{~min}$, and the constituent steel $\mathrm{FSS}_{\mathrm{F}}$ isothermally heated at $430^{\circ} \mathrm{C}$ for 5 min while SAAS is annealed. In this case the experimental CWL of SDSS is $0.0751 \mathrm{mg} / \mathrm{cm}^{2}$, while the calculated CWL is as high as 14.4041 $\mathrm{mg} / \mathrm{cm}^{2}$. The deviation between calculated and experimental CWL, is more than $100 \%$ in both cases, however it is much higher in case of ferrite transformation. This is an indication that a greater role is played by these condary precipitates on corrosion which is even higher in case of ferrite transformation $\alpha$-phase compared to austenitic transformation with $\sigma$-phase, carbides and nitrides.

Corrosion resistance in SDSS is not related to mechanical mixing of composite constituents, but depends mainly on resistance of the chromium oxide layer on the surface. Corrosion resistance is also dependent on the individual resistance of the austenite and ferrite primary phases in the duplex structure. It is concluded that ROM, although indicates the mechanical or toughness behavior, however it cannot be applied to calculate CWL.

\section{Conclusions}

1) ROM can be applied to express the toughness of super duplex stainless steel due to precipitation of intermetallic phases. The calculated toughness is 30\% greater than the experimental data, due to detrimental effect of the secondary precipitates formed with isothermal heat treatment.

2) In case of corrosion, ROM results in a great deviation of more than $100 \%$ between the calculated and experimental specific corrosion weight loss. However, this deviation is found to be greatly minimized in case of isothermal heat treatment at or close to the transformation temperature noses.

\section{References}

[1] Davis, J.R. (1994) ASM Speciality Handbook Stainless Steels, ASM International.

[2] ASTM A240 (2004) Standard Specification for Chromium and Chromium-Nickel Stainless Steel Plate, Sheet and Strip for Pressure Vessels and for General Applications.

[3] ASTM A276 (2004) Standard Specification for Stainless Steel Bars and Shapes.

[4] ASTM A564 (2004) Standard Specification for Hot-Rolled and Cold-Finished Age-Hardening Stainless Steel Bars and Shapes.

[5] Kato, Y., Ito, M., Kato, Y. and Furukimi, O. (2010) Effect of Si on Precipitation Behaviour of Nb-Laves Phase and Amount of $\mathrm{Nb}$ in Solid Solution at Elevated Temperature in High Purity $17 \% \mathrm{Cr}-0.5 \% \mathrm{Nb}$ Steels. Materials Transactions, 51, 1531-1535. http://dx.doi.org/10.2320/matertrans.M2010112

[6] Leffler, B. (2013) Stainless Steels and their Properties. http://www.hazmetal.com/f/kutu/1236776229.pdf

[7] Lo, K.H., Shek, C.H. and Lai, J.K.L. (2009) Recent Developments in Stainless Steels. Materials Science and Engineering $R$, 65, 39-104. http://dx.doi.org/10.1016/j.mser.2009.03.001

[8] Fontes, T.F. and R.M. (2011) Corrosion versus Mechanical Tests for Indirect Detection of Alpha Prime Phase in UNS S32520 Super Duplex Stainless Steel. Corrosion, 67, 1-7.

[9] Vitek, J.M., David, S.A., Alexander, D.J., Keiser, J.R. and Nanstad, R.K. (1991) Low Temperature Aging Behavior of Type 308 Stainless Steel Weld Metal. Acta Metallurgica et Materialia, 39, 503-516. http://dx.doi.org/10.1016/0956-7151(91)90118-K

[10] Grobner, P.J. (1973) The $885^{\circ} \mathrm{f}\left(475^{\circ} \mathrm{C}\right)$ Embrittlement of Ferritic Stainless Steels. Metallurgical Transactions, 4, 251260. http://dx.doi.org/10.1007/BF02649625

[11] Hattestrand, M., Larsson, P., Chai, G., Nilsson, J.-O. and Odqvist, J. (2009) Study of Decomposition of Ferrite in a Duplex Stainless Steel Cold Worked and Aged at $450^{\circ} \mathrm{C}-500^{\circ} \mathrm{C}$. Materials Science and Engineering: A, 499, 489-492.

http://dx.doi.org/10.1016/j.msea.2008.09.021 
[12] Abdullah, M.A. (2009) Structural Characterisation, Residual Stress Determination and Degree of Sensitisation of Duplex Stainless Steel Welds. Ph.D. Thesis, RMIT University, Melbourne.

[13] Hsieh, C.-C. and Wu, W. (2011) Overview of Intermetallic Sigma ( $\sigma$ ) Phase Precipitation in Stainless Steels. Taichung, Taiwan: International Scholarly Research Network ISRN Metallurgy, 2012, 16 p.

[14] Nilsson, J.-O. and Chai, G. (1997) The Physical Metallurgy of Duplex Stainless Steels. Sandvik Materials Technology, R\&D Centre, Sandviken.

[15] Chumbley, L.S. (2005) Final Report on Clean Cast Steel Technology: Determination of Transformation Diagrams for Duplex Stainless Steel. Iowa State University, Ames. http://dx.doi.org/10.2172/850237

[16] Francis, R. (2008) Zeron 100 Super Duplex Stainless Steel in Mining Industry. http://www.rolledalloys.com/shared/library/technical-papers/corrosive/Experiences-with-Zeron-100-Superduplex-Stain less-Steel-in-the-Process-Industry.pdf

[17] Thames Stock. http://www.thamesstock.com/downloads/UNS_32760_TSL.pdf

[18] ATI Allegheny Ludlum (2010) ATI-AL6XN Alloy (UNS N08367). https://www.atimetals.com/Documents/al-6xn_tds_en_V2.pdf

[19] Elsabbagh, F.M., Hamouda, R.M. and Taha, M.A. (2014) On Microstructure and Microhardness of Isothermally Aged UNS S32760 and the Effect on Toughness and Corrosion Behavior. Journal of Materials Engineering and Performance, 23, 275-284. http://dx.doi.org/10.1007/s11665-013-0619-7

[20] ASTM A182 (2013) Specification for Forged or Rolled Alloy and Stainless Steel Pipe Flanges, Forged Fittings, and Valves and Parts for High Temperature Service.

[21] ASTM G48 (2011) Standard Test Methods for Pitting and Crevice Corrosion Resistance of Stainless Steels and Related Alloys by Use of Ferric Chloride Solution. 